\title{
Synthesis and Biological Activity of Alkoxysulfenyl Derivatives of Methylcarbamate Insecticides
}

\author{
Mitsuyasu Kawata, Noriharu Umetsu, Takeshi Goto \\ and T. Roy Fukuto* \\ Naruto Research Center, Agrochemicals Research and Development Department, \\ Otsuka Chemical Co., Ltd., Satoura-cho, Naruto 772, Japan \\ *Division of Toxicology and Physiology, Department of Entomology, \\ University of California, Riverside, California 92521, U. S. A.
}

(Received February 18, 1988)

\begin{abstract}
A number of alkoxysulfenyl derivatives of insecticidal methylcarbamates were synthesized by the reaction between alcohols and $N$-chlorosulfenyl- $N$-methylcarbamate, the latter being prepared from the methylcarbamate and sulfur dichloride in the presence of base. Polysulfide analogs of the alkoxysulfenyl derivatives were also formed in significant amounts as byproducts by this method. The alkoxysulfenyl derivatives of phenyl carbamates proved to be stable, whereas the derivatives of oxime carbamates were unstable. All of the alkoxysulfenyl derivatized carbamates, with a few exceptions, showed high insecticidal activity against houseflies and green rice leafhoppers. Some of the derivatives of carbofuran (2,3-dihydro-2, 2-dimethyl-7-benzofuranyl $\mathrm{N}$-methylcarbamate) appeared more effective against houseflies than the parent carbofuran. Derivatization generally resulted in substantial improvement in toxicity to mice. Toxicity of the derivatives of carbofuran to mice systematically decreased with increase in carbon atoms in the straight chain alkoxy moiety. All the polysulfide analogs were insecticidal, and both the activity to houseflies and the toxicity to mice decreased with increase in the number of sulfur atoms in the molecule.
\end{abstract}

\section{INTRODUCTION}

Recent investigation $\mathrm{s}^{1-3)}$ have demonstrated that toxic methylcarbamate insecticides can be converted into a derivative with less mammalian toxicity and with other more favorable biological activities by appropriate substitution of the proton on the carbamyl nitrogen atom. During the past decade, a wide variety of derivatives of methylcarbamate insecticides with improved selectivity have been discovered. $N$-Acyl-, $N$-dialkoxyphosphinothioyl-, $N$-alkyl- and $N$-arylsulfenyl-, $N$ aminosulfenyl-, $N$-sulfinyl- and $N$-phosphoramidothio- $N$-methylcarbamates, and $N, N^{\prime}$ thiobiscarbamates are among the derivatives studied. ${ }^{1-4)}$ These derivatives showed sig- nificantly reduced toxicity to white mice and often possessed improved insecticidal activity.

During the course of a study on the behavior of carbosulfan (2,3-dihydro-2,2-dimethyl-7benzofuranyl $N$-dibutylaminothio- $N$-methylcarbamate), an aminosulfenyl derivative of carbofuran, under different solvent conditions, we discovered that carbosulfan was unstable in a methanol-acetic acid (9:1) or ethanol-acetic acid (9:1) mixture, being converted into the $N$-methoxysulfenyl (1) or $N$-ethoxysulfenyl (2) derivatives of carbofuran according to Eq. (a), and to a variety of other alteration products. ${ }^{5}$ These two new methylcarbamate derivatives (1 and 2) also showed reduced mammalian toxicity and still retained high insecticidal activity. 


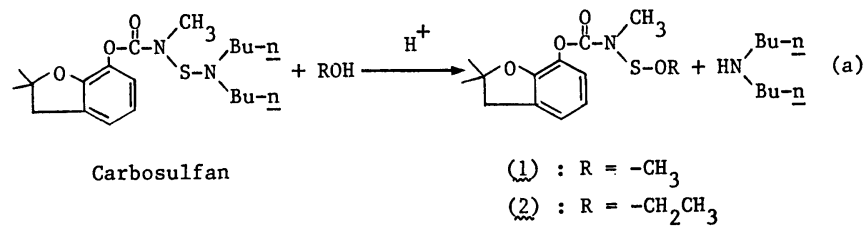

Because of the desired selectivity demonstrated by these $N$-alkoxysulfenyl- $N$-methylcarbamates, it was of interest to examine other derivatives of this type for biological activity. In addition to the reaction described by Eq. (a), several different attempts were made to synthesize alkoxysulfenyl derivatives of methylcarbamate. We found that the alkoxysulfenyl derivative can be prepared by simply adding an alcohol to an $N$-chlorosulfenyl- $N$-methylcarbamate prepared from methylcarbamate and sulfur dichloride in the presence of base. Polysulfide analogs of the alkoxysulfenyl derivatives were also formed in significant amounts as by-products by this method. We report hereon the synthesis and toxicological properties of a series of $N$-alkoxysulfenyl- $N$ methylcarbamate and their polysulfide analogs.

\section{MATERIALS AND METHODS}

\section{Synthesis of Compounds}

\subsection{General procedure}

The alkoxysulfenyl derivatives of methylcarbamates listed in Tables 1 and 2 were synthesized according to Eq. (b). The insecticidal methylcarbamates, carbofuran, propoxur (2-isopropoxyphenyl $N$-methylcarbamate) and MIP (3-isopropylphenyl $N$-methylcarbamate), which are designated as $\operatorname{ArOC}(\mathrm{O}) \mathrm{N}\left(\mathrm{CH}_{3}\right) \mathrm{H}$, were reacted with sulfur dichloride in the presence of such a base as triethylamine to form the corresponding sulfenyl chlorides. The chlorosulfenyl intermediates

Table 1 Physical and toxicological properties of the alkoxysulfenyl derivatives of carbofuran, propoxur and MIP.

\begin{tabular}{|c|c|c|c|c|c|}
\hline \multicolumn{2}{|c|}{ Compound } & \multirow[b]{2}{*}{$n_{\mathrm{D}}^{23}$} & \multirow{2}{*}{$\begin{array}{c}\text { Housefly } \\
\text { LD }_{50} \\
(\mu \mathrm{g} / \mathrm{g})\end{array}$} & \multirow{2}{*}{$\begin{array}{c}\text { Mouse oral } \\
\mathrm{LD}_{50} \\
(\mathrm{mg} / \mathrm{kg})\end{array}$} & Reference \\
\hline No. & $\mathrm{R}$ & & & & $\begin{array}{c}\left.\text { Polysulfide }{ }^{a}\right) \\
\text { derivative } \\
(\%)\end{array}$ \\
\hline
\end{tabular}

$\begin{array}{rlrrr} & & & & \\ \\ \end{array}$


Table 1 (continued)

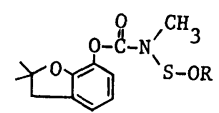

(Propoxur)

16

17

$\left(\mathrm{CH}_{2}\right)_{3} \mathrm{CH}_{3}$

$\mathrm{CH}_{2} \mathrm{C}_{6} \mathrm{H}_{5}$<smiles>Cc1ccc(OC(=O)N(C)SOc2ccccc2)cc1</smiles>

(MIP)

18

19
1.5103

1.5552
24.0

46.0

$62-15$
-1000

$30.0>1000 \quad 16$

a) Samples used in determination of toxicological properties contained the corresponding polysulfide analogs in the amounts indicated.

b) Samples prepared by Eq. (a) were used.

c) Not determined.

Table 2 Comparison of the methoxy- or hexyloxysulfenyl derivatives of carbofuran and their polysulfide analogs in physical and toxicological properties.

\begin{tabular}{|c|c|c|c|c|c|c|c|}
\hline \multirow{2}{*}{ No. } & & \multirow[b]{2}{*}{$n$} & \multirow[b]{2}{*}{$n_{\mathrm{D}}^{23}$} & \multicolumn{2}{|c|}{ Housefly $\mathrm{LD}_{50}$} & \multicolumn{2}{|c|}{ Mouse $\mathrm{LD}_{50}$} \\
\hline & $\mathrm{R}$ & & & $\mu \mathrm{g} / \mathrm{g}$ & $\mu \mathrm{mol} / \mathrm{g}$ & $\mathrm{mg} / \mathrm{kg}$ & $\mathrm{mmol} / \mathrm{kg}$ \\
\hline 1 & $\mathrm{CH}_{3}$ & 1 & 1.5339 & 15.5 & 0.0547 & 43 & 0.152 \\
\hline Ia & $\mathrm{CH}_{3}$ & 2 & 1.5500 & 20.5 & 0.0650 & 48 & 0.152 \\
\hline \multirow[t]{2}{*}{$\mathbf{1 b}$} & $\mathrm{CH}_{3}$ & $\geqq 3$ & 1.5530 & -a) & -a) & -a & -a) \\
\hline & $\mathrm{CH}_{3}$ & $\overline{1-n}$ & & 18.8 & & 40 & \\
\hline 9 & $\left(\mathrm{CH}_{2}\right)_{5} \mathrm{CH}_{3}$ & 1 & 1.5211 & 9.3 & 0.0263 & 37 & 0.105 \\
\hline $9 a$ & $\left(\mathrm{CH}_{2}\right)_{5} \mathrm{CH}_{3}$ & 2 & 1.5300 & 13.0 & 0.0337 & 72 & 0.187 \\
\hline \multirow[t]{3}{*}{$9 b$} & $\left(\mathrm{CH}_{2}\right)_{5} \mathrm{CH}_{3}$ & $\geqq 3$ & 1.5809 & 22.0 & $\left.0.0527^{b}\right)$ & 105 & $\left.0.251^{b}\right)$ \\
\hline & $\left(\mathrm{CH}_{2}\right)_{5} \mathrm{CH}_{3}$ & $1-n$ & & 14.5 & & 88 & \\
\hline & (Carbofuran) & & $\operatorname{mp} \begin{array}{l}150- \\
152^{\circ} \mathrm{C}\end{array}$ & 11.0 & 0.0497 & 11 & 0.050 \\
\hline
\end{tabular}

a) Not determined.

b) Calculation was based on $n=3$.

were then reacted with different kinds of alcohol in the presence of the base to give the alkoxysulfenyl derivatives of the methylcarbamates along with their polysulfide analogs $\left[\operatorname{ArOC}(\mathrm{O}) \mathrm{N}\left(\mathrm{CH}_{3}\right)\right.$ $\mathrm{S}_{n}$-OR, $\left.n=2,3, \ldots n\right]$ as by-products. In most cases, the polysulfide analogs were removed from the crude products by preparative thin-layer chromatography (TLC) to obtain pure alkoxysulfenyl derivatives. The polysulfide analogs of compounds $\mathbf{1}$ and $\mathbf{9}$ shown in Table 2 were isolated for structure analysis and toxicological studies. For these purposes, sulfur monochloride was used instead of sulfur dichloride to prepare a chlorosulfenyl intermediate in order to obtain the polysulfide analogs of $\mathbf{1}$ and $\mathbf{9}$ in larger amounts.

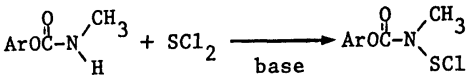

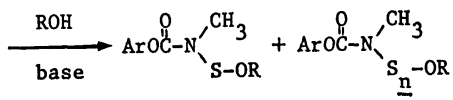


All derivatives were identified by ${ }^{1} \mathrm{H}$ NMR and electron impact mass spectra. ${ }^{1} \mathrm{H}$ NMR spectra were recorded on a Varian EM 390 spectrometer using $\mathrm{Me}_{4} \mathrm{Si}$ as the lock signal. Electron impact mass spectrometry was conducted with a Finnigan Model 1015 mass spectrometer.

As typical examples of the alkoxysulfenyl derivatives of carbofuran, propoxur, MIP and their polysulfide analogs, the preparation of compounds $\mathbf{3}, \mathbf{9}$, polysulfide analogs of $\mathbf{9}$, and $\mathbf{1 7}$ are given.

\subsection{Synthesis of 2,3-dihydro-2,2-dimethyl-7- benzofuranyl $\quad \mathrm{N}$-isopropoxysulfenyl-N- methylcarbamate (3)}

Sulfur dichloride $(5.2 \mathrm{~g}, \quad 0.051 \mathrm{~mol})$ in dichloromethane $(20 \mathrm{ml})$ was added to a stirred solution of carbofuran $(11.0 \mathrm{~g}, 0.050$ $\mathrm{mol})$ in dichloromethane $(100 \mathrm{ml})$ at $-5^{\circ} \mathrm{C}$. The resulting mixture was maintained at 0 to $5^{\circ} \mathrm{C}$ while a solution of triethylamine $(6.0 \mathrm{~g}$, $0.059 \mathrm{~mol})$ in dichloromethane $(20 \mathrm{ml})$ was added dropwise with stirring over $30 \mathrm{~min}$. The reaction mixture was allowed to come to room temperature and then stirred for $3 \mathrm{hr}$. To the resulting mixture was added dropwise a solution of 2-propanol $(3.0 \mathrm{~g}, 0.050 \mathrm{~mol})$ and triethylamine $(6.0 \mathrm{~g}, 0.059 \mathrm{~mol})$ in dichloromethane at $0^{\circ} \mathrm{C}$. After stirred for another $3 \mathrm{hr}$ at $0^{\circ} \mathrm{C}$, the mixture was again allowed to come to room temperature and washed three times with water. After dried over anhydrous sodium sulfate and concentrated, the residue was dissolved in $n$-hexane and allowed to stand until carbofuran $(2.5 \mathrm{~g})$ and $N, N^{\prime}$-thiobiscarbofuran $(2.9 \mathrm{~g})$ had precipitated. Evaporation of the filtrate yielded a viscous oily substance $(8.1 \mathrm{~g})$. The crude substance $(2.0 \mathrm{~g})$ was purified by silica gel preparative TLC (60 $\mathrm{F}_{254}$ plate, $1.0 \mathrm{~mm}$ thickness, EM Laboratories) using $n$-hexane-ether (7:3) as a developing solvent to give $1.4 \mathrm{~g}$ of oily product. To remove trace amounts of impurities, the oil was further subjected to preparative TLC using a reversed-phase silica gel plate $\left(\mathrm{KC}_{18}, 0.2 \mathrm{~mm}\right.$ thickness, Whatman Inc.) developed with acetonitrile-water $(9: 1)$, yielding the purified product, $n_{\mathrm{D}}^{23} 1.5402$ (light yellow oil). Yield: $36 \%$; NMR ( $\left.\mathrm{CDCl}_{3}-\mathrm{TMS}\right): \delta$ ppm $1.25(6 \mathrm{H}, \mathrm{d}$, $\left.J=6.1 \mathrm{~Hz}, \mathrm{OCH}\left(\mathrm{CH}_{3}\right)_{2}\right), 1.42\left(6 \mathrm{H}, \mathrm{s}, \mathrm{C}\left(\mathrm{CH}_{3}\right)_{2}\right)$, $3.02\left(2 \mathrm{H}\right.$, br. s, $\left.\mathrm{Ph}-\underline{\mathrm{CH}}_{2}\right), 3.53\left(3 \mathrm{H}, \mathrm{s}, \mathrm{NCH}_{3}\right)$, $4.40\left(1 \mathrm{H}\right.$, sep, $\left.J=6.1 \mathrm{~Hz}, \mathrm{OCH}\left(\mathrm{CH}_{3}\right)_{2}\right), 6.7-$ $7.1(3 \mathrm{H}, \mathrm{m}$, aromatic protons); mass spectrum $(70 \mathrm{eV}) \mathrm{m} / \mathrm{z}$ (relative intensity) 311 (4.1), 269 (16.3), 195 (8.0), 191 (2.3), 164 (100).

1.3 Synthesis of 2,3-dihydro-2,2-dimethyl-7benzofuranyl $N$-hexyloxysulfenyl-N-methylcarbamate (9)

To a solution of 2,3-dihydro-2,2-dimethyl-7benzofuranyl $N$-chlorosulfenyl- $N$-methylcarbamate prepared from $11.0 \mathrm{~g}(0.050 \mathrm{~mol})$ of carbofuran and $5.2 \mathrm{~g} \quad(0.050 \mathrm{~mol})$ of sulfur dichloride in dichloromethane as described in section 1.2, was added dropwise a solution of 1-hexanol $(5.1 \mathrm{~g}, 0.050 \mathrm{~mol})$ and triethylamine $(6.0 \mathrm{~g}, 0.059 \mathrm{~mol})$ in dichloromethane at $0^{\circ} \mathrm{C}$. The mixture was stirred for $3 \mathrm{hr}$ at $0^{\circ} \mathrm{C}$ and worked up as previously described in section 1.2.

A sample purified by silica gel and reversedphase TLC was obtained as a light yellow oil, $n_{\mathrm{D}}^{23} 1.5211$. Yield: $38 \%$; NMR ( $\left.\mathrm{CDCl}_{3}-\mathrm{TMS}\right)$ : $\delta$ ppm $0.90\left(3 \mathrm{H}\right.$, br. t, $\left.\mathrm{O}\left(\mathrm{CH}_{2}\right)_{5} \mathrm{CH}_{3}\right), 1.0-1.8$ $\left(8 \mathrm{H}, \mathrm{m}, \mathrm{OCH}_{2}\left(\mathrm{CH}_{2}\right)_{4} \mathrm{CH}_{3}\right), 1.48\left(6 \mathrm{H}, \mathrm{s}, \mathrm{C}\left(\mathrm{CH}_{3}\right)_{2}\right)$, $3.03\left(2 \mathrm{H}, \mathrm{s}, \mathrm{Ph}-\overline{\mathrm{CH}}_{2}\right), 3.57\left(3 \mathrm{H}, \mathrm{s}, \mathrm{N}-\mathrm{CH}_{3}\right), 4.10$ $\left(2 \mathrm{H}\right.$, br. t, $\left.\mathrm{OCH}_{2}\left(\mathrm{CH}_{2}\right)_{4}\right), 6.7-7.1 \overline{(3 \mathrm{H}, \mathrm{m}}$, aromatic protons); mass spectrum $(70 \mathrm{eV}) \mathrm{m} / \mathrm{z}$ (relative intensity) $353\left(\mathrm{M}^{+} 5.6\right), 269$ (11.3), 195 (6.9), 191 (3.1), 164 (100).

1.4 Synthesis of the polysulfide analogs of 2,3dihydro-2,2-dimethyl-7-benzofuranyl $N$ hexyloxysulfenyl-N-methylcarbamate $(\mathbf{9 a}$, 9b)

Sulfur monochloride $(6.8 \mathrm{~g}, 0.050 \mathrm{~mol})$ in dichloromethane $(20 \mathrm{ml})$ was added to a stirred solution of carbofuran $(11.0 \mathrm{~g}, 0.050$ $\mathrm{mol})$ in dichloromethane $(80 \mathrm{ml})$ at $-5^{\circ} \mathrm{C}$. The resulting mixture was maintained at 0 to $5^{\circ} \mathrm{C}$, and a solution of triethylamine $(5.5 \mathrm{~g}, 0.054$ $\mathrm{mol})$ in dichloromethane $(25 \mathrm{ml})$ was added dropwise to the mixture with stirring for more than $30 \mathrm{~min}$. The reaction mixture was allowed to come to room temperature and stirred for $3 \mathrm{hr}$. The mixture was chilled to $0^{\circ} \mathrm{C}$ and a solution of 1-hexanol $(5.2 \mathrm{~g}, 0.051$ $\mathrm{mol})$ and triethylamine $(5.5 \mathrm{~g}, 0.054 \mathrm{~mol})$ in dichloromethane $(20 \mathrm{ml})$ was added dropwise. After stirred for another $3 \mathrm{hr}$ at $0^{\circ} \mathrm{C}$, the mixture was allowed to come to room temperature and worked up as previously described to obtain a mixture of compound (9) and its polysulfide analogs. 
The mixture thus obtained (2.6 g) was purified by silica gel preparative TLC using $n$ hexane-ether $(7: 3)$ as a developing solvent to give $1.60 \mathrm{~g}$ of oil. This oil $(1.57 \mathrm{~g})$ was further subjected to preparative TLC using benzeneacetonitrile $(49: 1)$ as a solvent. Fraction 1 $(R f: 0.69-0.77)$ and fraction 2 (Rf: 0.47-0.69) were both extracted into dichloromethane, and the removal of the solvent gave $208 \mathrm{mg}$ of fraction 1 and $1.05 \mathrm{~g}$ of fraction 2 .

Fraction 1 was a mixture of the polysulfide derivatives of 2,3-dihydro-2,2-dimethyl-7-benzofuranyl $\quad N$-hexyloxysulfenyl- $N$-methylcarbamate (designated as $\mathrm{CF}-\mathrm{S}_{n}-\mathrm{OC}_{6} \mathrm{H}_{13}$ where $n \geqq 3, \mathbf{9 b}$ ), whose structure is shown below:

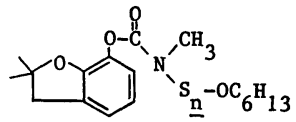

$n_{\mathrm{D}}^{23}$ 1.5809. $\mathrm{NMR}\left(\mathrm{CDCl}_{3}-\mathrm{TMS}\right): \delta \mathrm{ppm} 0.90$ $\left(3 \mathrm{H}\right.$, br. $\left.\mathrm{t}, \mathrm{O}\left(\mathrm{CH}_{2}\right)_{5} \mathrm{CH}_{3}\right), \quad 1.0-1.8(8 \mathrm{H}, \mathrm{m}$, $\left.\mathrm{OCH}_{2}\left(\mathrm{CH}_{2}\right)_{4} \mathrm{CH}_{3}\right), \quad 1.48\left(6 \mathrm{H}, \mathrm{s}, \mathrm{C}\left(\mathrm{CH}_{3}\right)_{2}\right), 3.05$ $\left(2 \mathrm{H}, \mathrm{s}, \mathrm{Ph}-\mathrm{CH}_{2}\right), 3.37-3.47\left(3 \mathrm{H}, \mathrm{m}, \mathrm{NCH}_{3}\right)$, $3.92\left(2 \mathrm{H}\right.$, br. t, $\left.\mathrm{OCH}_{2}\left(\mathrm{CH}_{2}\right)_{4}\right), 6.7-7.1(3 \mathrm{H}, \mathrm{m}$, aromatic protons); mass spectrum $(70 \mathrm{eV}) \mathrm{m} / \mathrm{z}$ 481, 449, 417, 385 (molecular ion peaks).

Fraction 2 (606 mg) was further subjected to preparative TLC using a silica gel reversedphase plate and acetonitrile (1st migration) and acetonitrile-water (9:1, 2nd migration) as solvents. Fraction 2-a (Rf: 0.67-0.75) and 2-b $(R f: 0.56-0.66)$ were extracted into ether, and the removal of the solvent gave $282 \mathrm{mg}$ of 2-a and $204 \mathrm{mg}$ of 2-b. The TLC properties, NMR and MS data of 2-a agreed with those of 2,3-dihydro-2,2-dimethyl-7-benzofuranyl $\mathrm{N}$ hexyloxysulfenyl- $N$-methylcarbamate (CF-S$\left.\mathrm{OC}_{6} \mathrm{H}_{13}, 9\right)$ described in section 1.3.

Fraction 2-b was the disulfide derivative of 2,3-dihydro-2,2-dimethyl-7-benzofuranyl $\mathrm{N}$ hexyloxysulfenyl- $N$-methylcarbamate $\left(\mathrm{CF}-\mathrm{S}_{2}-\right.$ $\left.\mathrm{OC}_{6} \mathrm{H}_{13}, 9 a\right) . \quad n_{\mathrm{D}}^{23}$ 1.5300. NMR ( $\left.\mathrm{CDCl}_{3}-\mathrm{TMS}\right)$ : $\delta$ ppm $0.90\left(3 \mathrm{H}\right.$, br. t, $\left.\mathrm{O}\left(\mathrm{CH}_{2}\right)_{5} \mathrm{CH}_{3}\right), 1.0-1.8$ $\left(8 \mathrm{H}, \quad \mathrm{m}, \quad \mathrm{OCH}_{2}\left(\mathrm{CH}_{2}\right)_{4} \mathrm{CH}_{3}\right), \quad 1.48(6 \mathrm{H}, \mathrm{s}$, $\left.\mathrm{C}\left(\mathrm{CH}_{3}\right)_{2}\right), 3.05\left(2 \mathrm{H}, \mathrm{s}, \mathrm{Ph}-\mathrm{CH}_{2}\right), 3.38(3 \mathrm{H}, \mathrm{s}$, $\left.\mathrm{NCH}_{3}\right), 3.90$ (2H, br. t, $\left.\mathrm{OCH}_{2}\left(\mathrm{CH}_{2}\right)_{4}\right), 6.7-7.1$ $(3 \mathrm{H}, \mathrm{m}$, aromatic protons); mass spectrum $(70 \mathrm{eV}) \mathrm{m} / \mathrm{z}$ (relative intensity) $385\left(\mathrm{M}^{+} 1.2\right)$ 353 (0.3), 328 (1.1), 269 (0.6), 195 (1.4), 167 (4.1), 164 (19.7), 163 (100).

\subsection{Synthesis of 2-isopropoxyphenyl N-ben-} zyloxysulfenyl-N-methylcarbamate (17)

To a chilled solution of 2-isopropoxyphenyl $N$-chlorosulfenyl- $N$-methylcarbamate prepared from $1.9 \mathrm{~g}(0.0091 \mathrm{~mol})$ of 2-isopropoxyphenyl $\mathrm{N}$-methylcarbamate (propoxur) and $1.0 \mathrm{~g}$ $(0.0097 \mathrm{~mol})$ of sulfur dichloride in dichloromethane at $0^{\circ} \mathrm{C}$ was added dropwise a solution of benzyl alcohol $(1.1 \mathrm{~g}, 0.010 \mathrm{~mol})$ and triethylamine $(1.2 \mathrm{~g}, 0.011 \mathrm{~mol})$ in dichloromethane. The mixture was stirred for $3 \mathrm{hr}$ at $0^{\circ} \mathrm{C}$ and worked up in the similar manner to the previous examples.

A sample was purified by TLC as previously described to give pure 17, $n_{\mathrm{D}}^{23}$ 1.5552. Yield: $42 \%$; NMR ( $\left.\mathrm{CDCl}_{3}-\mathrm{TMS}\right): \delta$ ppm $1.26(6 \mathrm{H}, \mathrm{d}$, $\left.J=6 \mathrm{~Hz}, \mathrm{OCH}\left(\mathrm{CH}_{3}\right)_{2}\right), 3.56\left(3 \mathrm{H}, \mathrm{s}, \mathrm{NCH}_{3}\right), 4.51$ $\left(1 \mathrm{H}\right.$, sep, $\left.J=6 \mathrm{~Hz}, \mathrm{OCH}\left(\mathrm{CH}_{3}\right)_{2}\right), 5.10$ (2H, s, $\left.\mathrm{OCH}_{2} \mathrm{C}_{6} \mathrm{H}_{5}\right), 6.8-7.5$ (9. H, m, aromatic protons); mass spectrum $(70 \mathrm{eV}) \mathrm{m} / z 347\left(\mathrm{M}^{+}\right)$.

\section{Mouse Toxicity}

Toxicity to mice was determined orally on Swiss white mice (Simonsen Laboratories, Gilroy, CA) using corn oil as a carrier according to the previously described procedure. ${ }^{6}$ ) Animals weighing between 25 and $28 \mathrm{~g}$ received 1-ml suspension of each test compound per $100 \mathrm{~g}$ of body weight. Based on 7-dayaccumulative mortality, $\mathrm{LD}_{50}$ values were calculated by the Probit method.

\section{Insecticidal Activity}

Toxicity to houseflies was determined on a susceptible NAIDM strain of 4-day-old female houseflies, Musca domestica, according to the usual procedure. ${ }^{7)}$ One microliter of acetone solution of each compound was topically applied with an Arnold Hand Microapplicator onto the thorax of ten houseflies. The treated flies were held at $25^{\circ} \mathrm{C}$, and their mortality was estimated after $24 \mathrm{hr}$. Data are means of three replications.

$\mathrm{LD}_{50}$ values of the compounds against susceptible (Miyagi) and resistant (Nakagawara) strains of 5- to 7-day-old female green rice leafhopper, Nephotettix cincticeps, were determined by the same method used for the housefly toxicity determination. In this case, the volume of acetone solution was $0.5 \mu \mathrm{l}$ per insect. 


\section{RESULTS AND DISCUSSION}

\section{Synthesis}

Three different methods were initially examined to synthesize a series of alkoxysulfenyl derivatives of carbofuran: the reaction of carbosulfan with alcohol in the presence of acetic acid (Eq. (a)), the reaction between $N$ chlorosulfenylcarbofuran and alcohol in the presence of base (Eq. (b)), and the reaction between $N$-chlorosulfenylcarbofuran and sodium alkoxide (Eq. (c)).

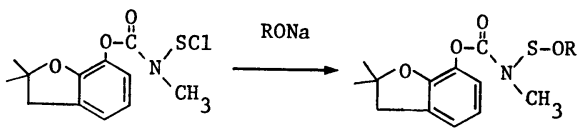

$N$-Methoxy- (1), $N$-ethoxy- (2), $N$-isopropoxy- (3), $N$-hexyloxy- $(\mathbf{9})$ and $N$-cyclohexyloxysulfenyl- $N$-methylcarbamate $(\mathbf{7})$ were prepared according to Eq. (a), but the reaction was not studied in detail because of the difficulty in removing the alcohols (especially longer chain alcohols) added as part of the reaction mixture and the difficulty in separating the products from carbosulfan whose TLC properties were similar. Subsequently, $N$ ethoxysulfenylcarbofuran (2) was prepared from $N$-chlorosulfenylcarbofuran, prepared from carbofuran and sulfur dichloride, and sodium ethoxide (Eq. (c)). The product was confirmed to be identical with the one prepared according to Eq. (a). Another discovery was that the alkoxysulfenyl derivatives could be prepared by simply adding an alcohol to $N$ chlorosulfenylcarbofuran, in the presence of triethylamine according to Eq. (b). The alkoxysulfenyl derivatives of propoxur and MIP could also be prepared according to Eq. (b). All of the products were obtained as oil, except for compound $\mathbf{8}$, which was a crystalline solid ( $\left.\mathrm{mp} 42-45^{\circ} \mathrm{C}\right)$. Total yield (based on the starting methylcarbamates) was $35-50 \%$ for all products. The relatively poor yield was attributed to the formation of the polysulfide analogs of alkoxysulfenyl derivatives as impurities and necessary chromatographic purification procedures to remove these polysulfide analogs.

Whereas the alkoxysulfenyl derivatives of carbofuran prepared according to Eq. (a) were free from their polysulfide analogs, all the derivatives prepared from carbofuran, propoxur or MIP according to Eq. (b) were a mixture of the alkoxysulfenyl derivative (77-95\%) and its polysulfide analogs (5-23\%). These two components were not separable by normalphase silica gel TLC and appeared to compose a single spot (two spots in some cases) with several different solvent systems. However, as exemplified with the hexyloxysulfenyl derivative of carbofuran (9) and its polysulfide derivatives, the mixture was separated into at least 7-8 components by $\mathrm{KC}_{18}$ reversed-phase TLC using acetonitrile as the developing solvent (see Fig. 1). Polysulfide analogs of 9 $\left(\mathrm{CF}-\mathrm{S}_{n}-\mathrm{OC}_{6} \mathrm{H}_{13}, n=2-5\right)$ were identified in the same manner as the polysulfide analogs of

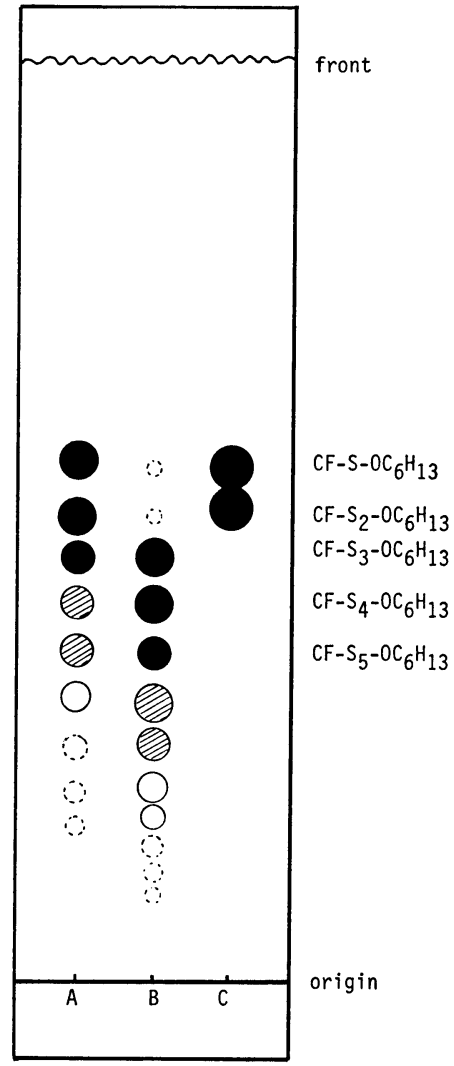

Fig. 1 Reversed-phase $\mathrm{KC}_{18}$ silica gel thin-layer chromatograms of the crude hexyloxysulfenyl derivative of carbofuran (A, CF- $\mathrm{S}_{n}-\mathrm{OC}_{6} \mathrm{H}_{13}, n=$ $1-n)$, and fraction 1 (B) and fraction 2 (C) obtained by normal-phase silica gel preparative TLC purification.

Solvent: acetonitrile. 
the methoxysulfenyl derivative $\left(\mathrm{CF}-\mathrm{S}_{n}-\mathrm{OCH}_{3}\right.$, $n=2-6),{ }^{5)}$ i.e., by ${ }^{1} \mathrm{H}$ NMR and mass spectroscopy.

In the preparation of the $\mathrm{N}$-chlorosulfenylcarbamate intermediate from the carbamate ester, sulfur dichloride was usually used. However, sulfur monochloride can be used instead of sulfur dichloride, but this results in a final product which contains polysulfide derivatives in larger amounts.

Although aminosulfenic acid esters are generally considered unstable, the alkoxysulfenyl derivatives of phenyl carbamates listed in Table 1 proved to be stable. However, the $\mathrm{N}$-alkoxysulfenyl derivatives of oxime carbamates were not stable. Attempts to synthesize $N$-ethoxy- and $N$-methoxysulfenyl derivatives of methomyl (S-methyl $N$ [(methylcarbamoyl)oxy]thioacetimidate) were made by use of the same method described by Eq. (b). Methomyl was reacted with sulfur dichloride, followed by ethanol in the presence of triethylamine (Eq. (b)). Small amounts (yield: $5-10 \%$ ) of product $\mathbf{2 0}$ was obtained. The NMR (in $\mathrm{CDCl}_{3}$ ) spectrum of TLCpurified material showed $[\delta \mathrm{ppm}: 1.23(3 \mathrm{H}, \mathrm{t}$, $\left.J=7 \mathrm{~Hz}, \mathrm{OCH}_{2} \mathrm{CH}_{3}\right), 2.30\left(3 \mathrm{H}, \mathrm{s},=\mathrm{C}-\mathrm{CH}_{3}\right)$, $2.40\left(3 \mathrm{H}, \mathrm{s},=\mathrm{C}-\mathrm{S}-\mathrm{CH}_{3}\right), 3.51\left(3 \mathrm{H}, \mathrm{s}, \mathrm{NCH}_{3}\right)$, $\left.4.09\left(2 \mathrm{H}, \mathrm{q}, J=7 \mathrm{~Hz}, \mathrm{OCH}_{2} \mathrm{CH}_{3}\right)\right]$, thus confirming the structure of $\mathbf{2 0}$. However, the $\mathbf{2 0}$ was not stable and completely decomposed in 3 days at $23^{\circ} \mathrm{C}$. The same reaction aimed at obtaining $2 \mathbf{1}$ was unsuccessful.

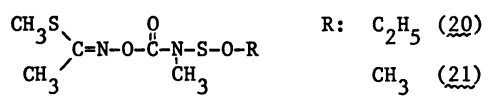

The formation of the alkoxysulfenyl derivative of methylcarbamate was easily confirmed by comparison of ${ }^{1} \mathrm{H}$ NMR spectrum of the derivative with that of the parent methylcarbamate. For example, the $N$-methyl protons of the derivatives of carbofuran showed a singlet and a downfield shift ( $\delta 3.36-3.59)$ as compared to a doublet and upfield absorption ( $\delta 2.87$ ) of the $N$-methyl protons of carbofuran.

\section{Toxicological Properties}

Data on the toxicity of the alkoxysulfenyl derivatives of carbofuran, propoxur and MIP to houseflies and mice are given in Table 1 . Because of the difficulty in obtaining large amounts of each compound free from its polysulfide derivatives, samples containing the corresponding polysulfide analogs in the amounts indicated (5-20\%) were used in toxicity determination.

In general, the alkoxysulfenyl derivatives of carbofuran and propoxur showed high insecticidal activity against the houseflies by topical application, whereas the derivatives of MIP were relatively poor in insecticidal activity. Two of the derivatives of carbofuran, compounds $\mathbf{8}$ and $\mathbf{1 1}$ appeared more effective against the houseflies than the parent methylcarbamate, carbofuran, on a weight basis. Six additional derivatives, compounds $\mathbf{9}, \mathbf{1 0}, \mathbf{1 2}$, 14, 15 and $\mathbf{1 7}$ were superior to the parent methylcarbamate on a molar basis, although $\mathrm{LD}_{50}$ values based on a molar basis are not shown in Table 1.

The data presented in Table 1 show that compared to the original methylcarbamates, carbofuran (oral LD $5011 \mathrm{mg} / \mathrm{kg}$ ), propoxur $(62$ $\mathrm{mg} / \mathrm{kg}$ ) and MIP (16 mg/kg), all of the alkoxysulfenyl derivatives were less toxic to the mice than their respective parent methylcarbamates. In fact, the carbofuran derivatives $12\left(\mathrm{LD}_{50}\right.$ $340 \mathrm{mg} / \mathrm{kg})$ and $\mathbf{1 3}(>1000 \mathrm{mg} / \mathrm{kg})$ were less toxic to the mice than any other sulfenylated derivatives of carbofuran previously examined in our laboratories. ${ }^{1-4)}$ The toxicity of the propoxur derivatives $\mathbf{1 6}$ and $\mathbf{1 7}$ were also remarkably reduced, $\mathrm{LD}_{50}$ being over 1000 $\mathrm{mg} / \mathrm{kg}$. There was some correlation between the structure of substituent and mouse toxicity. For example, toxicity of the derivatives of carbofuran to the mice systematically decreased with increase in the number of carbon atoms in the straight chain alkoxy moiety. No obvious correlation was apparent with the other substituents.

Comparison of the toxicological properties between the alkoxysulfenyl derivatives of carbofuran and their polysulfide analogs was made with two representative derivatives, the methoxysulfenyl derivative $\left(\mathbf{1}, \mathrm{CF}-\mathrm{S}-\mathrm{OCH}_{3}\right)$ and the hexyloxysulfenyl derivative (9, CF-S$\left.\mathrm{OC}_{6} \mathrm{H}_{13}\right)$. Because of the difficulty in obtaining purified samples, data are limited only to the monosulfide derivative (CF-S-OCH $3, \mathrm{CF}-\mathrm{S}$ $\left.\mathrm{OC}_{6} \mathrm{H}_{13}\right)$, disulfide analogs $\left(\mathrm{CF}-\mathrm{S}_{2}-\mathrm{OCH}_{3}\right.$ and $\left.\mathrm{CF}-\mathrm{S}_{2}-\mathrm{OC}_{6} \mathrm{H}_{13}\right)$, trisulfide plus polysulfide ana- 
Table 3 Insecticidal activity of alkoxysulfenyl derivatives of carbofuran to susceptible and resistant green rice leafhoppers.

\begin{tabular}{|c|c|c|c|}
\hline \multirow{3}{*}{ No. } & \multirow{3}{*}{$\underbrace{0}_{R}$} & \multicolumn{2}{|c|}{$\mathrm{LD}_{50}(\mu \mathrm{g} / \mathrm{g})$} \\
\hline & & \multicolumn{2}{|c|}{ Green rice leafhopper } \\
\hline & & S-strain & R-strain \\
\hline 3 & $\mathrm{CH}\left(\mathrm{CH}_{3}\right)_{2}$ & 6.6 & 12.3 \\
\hline 4 & $\mathrm{C}\left(\mathrm{CH}_{3}\right)_{3}$ & 5.7 & 12.1 \\
\hline 6 & $\mathrm{CH}\left(\mathrm{CH}_{2} \mathrm{CH}_{3}\right)_{2}$ & 5.4 & 12.2 \\
\hline 7 & Cyclohexyl & 15.7 & 56.9 \\
\hline 8 & $\mathrm{CH}_{2} \mathrm{C}_{6} \mathrm{H}_{5}$ & 8.9 & 28.5 \\
\hline 10 & $\left(\mathrm{CH}_{2}\right)_{7} \mathrm{CH}_{3}$ & 6.0 & 15.0 \\
\hline 11 & $\left(\mathrm{CH}_{2}\right)_{9} \mathrm{CH}_{3}$ & 16.2 & 35.7 \\
\hline 12 & $\left(\mathrm{CH}_{2}\right)_{11} \mathrm{CH}_{3}$ & 14.0 & 35.4 \\
\hline 13 & $\left(\mathrm{CH}_{2}\right)_{17} \mathrm{CH}_{3}$ & 57.0 & 183.8 \\
\hline 14 & $\mathrm{CH}_{2} \mathrm{C}_{6} \mathrm{H}_{4}-p-\mathrm{C}\left(\mathrm{CH}_{3}\right)_{3}$ & 5.4 & 12.2 \\
\hline 15 & $\mathrm{CH}_{2} \mathrm{C}_{6} \mathrm{H}_{4}-p-\mathrm{OCH}_{3}$ & 11.8 & 24.3 \\
\hline & (Carbofuran) & 3.9 & 11.5 \\
\hline
\end{tabular}

logs $(n \geqq 3)$, and crude mixture $(n=1-n)$. As shown in Table 2, all of the polysulfide analogs used in the determination were insecticidal, and both the activity to the houseflies and the toxicity to the mice decreased with increase in the number of sulfur atoms in the molecule. For example, 9b (CF-S $n^{-}$ $\mathrm{OC}_{6} \mathrm{H}_{13}, n \geqq 3$ ) was twofold less toxic than the monosulfide derivative (9) to the houseflies and $\mathbf{9 b}$ was 2.5 -fold less toxic to the mice than 9 on a molar basis.

Encouraged by the excellent insecticidal activity of the alkoxysulfenyl derivatives of carbofuran, we examined the effectiveness of some of the derivatives against agricultural pests. Table 3 summarizes data on the insecticidal activity of the alkoxysulfenyl derivatives of carbofuran to both susceptible (S) and resistant (R) strains of green rice leafhoppers. Most of the derivatives, with a few exceptions, showed high insecticidal activity to both strains. Although all of the derivatives were less active against the S-strain than the parent carbofuran on a weight basis, some compounds $(6,10,14)$ appeared more effective on a molar basis. In a case of the R-strain, compounds 3, 4, 6 and 14 were as effective as carbofuran even on a weight basis. Although data are not shown in the table, the alkoxysulfenyl derivatives were also effective against green peach aphids (Myzus persicae) and brown rice planthoppers (Nilaparvata lugens). ${ }^{8)}$

Earlier studies on the metabolism and the mode of action of derivatized methylcarbamate esters have shown that their lower mammalian toxicity is attributable to preferential metabolic detoxication of the derivative to nontoxic phenols. ${ }^{1,4}$ The same explanation can be possible for the mammalian safety of the alkoxysulfenyl derivatives. As exemplified with the derivative of carbofuran, cleavage at point (1) or (2) in the structural formula shown below would result in nontoxic products.

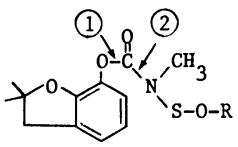

\section{REFERENCES}

1) T. R. Fukuto: J. Pesticide Sci. 2, 541 (1977)

2) T. R. Fukuto: "Pesticide Chemistry: Human Welfare and the Environment," ed. by J. Miyamoto \& P. C. Kearney, Vol. 1, Pergamon Press, Oxford, p. 203, 1983

3) N. Umetsu: J. Pesticide Sci. 9, 169 (1984)

4) T. Goto, N. Yasudomi, A. K. Tanaka, N. Osaki, H. Takao, M. Kawata, J. Imada, Y. Endo \& N. Umetsu: J. Pesticide Sci. 13, 39 (1988)

5) N. Umetsu, T. Nishioka \& T. R. Fukuto: $J$. Agric. Food Chem. 32, 765 (1984)

6) R. M. Hollingworth, T. R. Fukuto \& R. L. Metcalf: J. Agric. Food Chem. 15, 235 (1967) 
7) R. L. Metcalf \& R. B. March: J. Econ. Entomol. 42, 721 (1949)

8) N. Yasudomi, M. Kawata \& N. Umetsu: unpublished.

\section{要約}

\section{メチルカーバメート系殺蝓のアルコキシスル}

\section{フェニル誘導体の合成と生物活性}

川田充康, 梅津憲治, 後藤武司, T. Roy Fukuto

カーバメート系殺虫剤のアルコキシスルフェニル誘導 体を多数合成し，誘導体の諸性質および生物活性につい て検討した. 誘導体はメチルカーバメート剂と二塩化イ オウとの反応により得られるクロロスルフェニル中間体 に塩基存在下アルコールを反応させることにより得た。 本反応においては, 副生物としてアルコキシスルフェニ
ル誘導体のポリスルフィド類縁体が生成した。このよう にして得られたフェニルカーバメート剤の誘導体は安定 であったが，オキシムカーバメート剂の誘導体は不安定 であった，一部の例外を除き，合成したすべての誘導体 がイエバエとツマグロヨコバイに対し高い活性を示し, カルボフラン (2,3-ジヒドロ-2,2-ジメチル-7-ベンゾフ ラニル $N$-メチルカルバマート) 誘導体の中にはイエバ エに対し親化合物であるカルボフランよりも高い活性を 示す化合物も認められた。一方，すべての誘導体におい て親化合物よりも著しく毒性が軽減されていた。 カルボ フランの直鎖アルコキシスルフェニル誘導体では，炭素 数の増加に従って毒性の低下する傾向が䜑められた。 ポ リスルフィド類縁体はいずれも殺虫活性を示し，イオウ の数の増加に従って活性, 毒性ともに減少する傾向が認 められた。 